\title{
FINANCIAL MARKETS, PUBLIC POLICY, AND THE EAST ASIAN MIRACLE
}

\author{
Joseph E. Stiglitz \\ Marilou Uy
}

Many factors contributed to the rapid growth of the economies of East Asia in the past quarter century. This article examines one important aspect of that growth-commonly referred to as the "East Asian miracle"-public policies affecting the financial markets. East Asian governments intervened extensively in financial markets at all stages of their development. What sets their actions apart from those of other developing countries that have not fared as well? We do not have the information to answer conclusively what effect particular actions had (that requires a counterfactual test of what growth would have been without the particular intervention). But we can identify the market failures the East Asian governments addressed, assess some of the theoretical reasons why each policy might be growth enhancing, and provide some data attesting to the impacts of the policy. Several characteristics of financial sector interventions in East Asia stand out: they incorporated design features that improved the chances of success and reduced opportunities for abuse; interventions that did not work out were dropped unhesitatingly; and policies were adapted to reflect changing economic conditions.

$\mathrm{T}$ he economies of East Asia, beginning with Japan and followed by the Four Tigers-the Republic of Korea, Hong Kong, Singapore, and Taiwan (China)-and then by Malaysia, Indonesia, and Thailand, have grown so rapidly during the past quarter century that their growth has been called the "East Asian miracle." What lessons for other countries can be derived from this experience, assuming that it was not really a miracle, but rather a consequence of some well-designed programs and policies? In particular, what can be learned from the policies affecting financial markets? East Asian governments have intervened intensively in the operations of their financial systems. They have helped create financial markets and institutions, regulated them heavily, and directed credit to some indus- 
tries and away from others. These actions have been intended to mobilize savings and to affect the allocation of investment, but their effects have extended well beyond the capital market: the "prize" of scarce credit, awarded for good export performance, has provided strong investment incentives.

Careful examination of the interventions provides insights into the importance of specific design features that increased the likelihood that the interventions would work and decreased the likelihood of abuses. ${ }^{1}$ Government flexibility was also important. When programs failed, the interventions behind them were abandoned, and as economies changed, so did the role of governments. These general precepts, more than the particular interventions adopted, may prove to be the most important insights that other developing countries can borrow from the East Asian miracle.

Government interventions were directed at two broad objectives. The first is straightforward: making financial markets and institutions work better. Without the intermediation provided by capital markets, firms would have to rely solely on retained earnings for their investments, and firms' expected marginal private returns from investment would diverge markedly, especially in the short run. When capital markets work well, marginal returns are equated in all sectors and firms. Moreover, by spreading and pooling risks more broadly, capital markets lower risk premiums, so firms can undertake investments with greater risks and higher expected returns.

But even if the marginal private returns from investment are equated in all sectors and firms, capital may not be allocated efficiently if there are systematic deviations between private and social returns. Thus the second objective of government intervention in financial markets is to correct any resulting misallocation of resources.

Government financial policies are of three types: creating markets and financial institutions; regulating them; and providing rewards (subsidies or access to credit or foreign exchange, often on preferential terms) to firms, groups, or industries that undertake priority activities or perform in an exemplary manner. The East Asian economies had high national saving rates, achieved largely by voluntary actions, and they were able to invest their savings in ways that yielded high returns. Government interventions in the financial market that promoted savings and the efficient allocation of capital were central to these successes. Five of the more important interventions are examined here: promoting savings, regulating banks to fortify their solvency, creating financial institutions and markets, enforcing financial restraint, and intervening directly in the allocation of credit.

\section{Promoting Savings}

East Asian governments promoted national saving in several ways, from creating financial institutions and regulating them to running small fiscal deficits or even surpluses. 


\section{Creating Postal Savings and Provident Funds}

The postal saving systems in Japan, Malaysia, Singapore, and Taiwan (China) were the most important of the institutions governments created to promote savings. These systems attracted multitudes of small savers by giving them security and convenient access. When Japan's postal saving system was created in 1875 , other financial institutions had commonly excluded small savers or discouraged them by paying low interest rates or requiring minimum deposits too high for small savers (Mukai 1963). The postal saving system also provided convenient access through an extensive branch network of post offices, especially in rural areas (Yoshino 1992, Shea 1993, and Chiu 1992). Japan further encouraged postal savings by exempting the interest paid on postal deposits from income tax (until 1988); Taiwan (China) since 1965 and Korea do the same below a certain threshold.

The postal saving banks mobilized huge amounts of saving-up to 25 percent of national saving in Japan since the 1950s, 20 percent in Taiwan (China), and 12 percent in Singapore. In Japan postal saving was particularly important during periods of financial distress, when confidence in commercial banks waned. During the 1920s, for example, when the banks became unstable, households shifted their savings from banks to postal savings. In 1920 demand deposits in banks were six times the amount held in postal savings; by 1930 they had dwindled to just twice that amount.

Although the positive role of postal saving is generally acknowledged, the compulsory pension plans of Malaysia and Singapore are more controversial. Two rationales are given for such plans. First, most developing countries lack private annuity markets, and the few that exist are barely functional. Indexed annuities, for example, are rarely available, and nonindexed annuities are often priced unattractively because of large transactions costs and problems of adverse selection. In Malaysia and Singapore not only did the government provide the annuities, but it also required individuals to participate in the plans. This leads to the second rationale: even when annuities are available, people may not save enough for their old age, and governments end up assisting elderly people who are unable to support themselves. To avoid this free-rider problem, government may require citizens to have at least a minimum level of savings for retirement.

Unlike the social security systems of Europe and the United States, East Asia's programs were fully funded rather than pay-as-you-go. The distinction is important because fully funded systems are more likely to increase the national saving rate. Also setting them apart from U.S. and European systems were the extremely high required contribution rates (up to 50 percent of salaries in Singapore and 28 percent in Malaysia) and the fact that the savings covered not just retirement but other purposes as well, such as providing the down payment for housing.

The impact of provident funds on aggregate saving depends on how much voluntary saving they displace. In East Asia displacement does not appear to have been a 
problem: private pension schemes grew alongside public ones as individuals pursued ways to support increased consumption during retirement. At worst the pension funds' negative effects were so small that aggregate saving still increased. Dekle (1990) finds little empirical support of a negative effect of pension funds on private saving in Japan, while Noguchi (1985) finds a small negative effect. Singapore's Central Provident Fund had a positive effect on aggregate saving: had provident fund contributions remained at 10 percent, their required level in 1966, instead of rising to 35 percent during the 1970 s and to 50 percent during the 1980 s, average saving rates over the past two decades would have been about 4 percentage points lower (Monetary Authority of Singapore 1991).

\section{Regulating to Encourage Saving}

Governments used three types of regulations to influence national saving rates. Some regulations were designed to discourage consumption, some to enhance the safety and soundness of private financial intermediaries, and some to transfer resources from households to corporations.

RESTRICTIONS ON CONSUMER CREDIT. Most East Asian governments discouraged consumption by deliberately preventing mortgage markets and other instruments of consumer credit from developing. With little or no consumer credit available to purchase housing, consumer durables, and other goods, households were forced to save the full amount if they wanted to buy a house or make other large purchases. Although demand for consumer durables increases with household incomes, consumers could not borrow to buy these goods, so savings as a share of income rose rapidly. There is evidence that constraints on liquidity and on the development of consumer credit markets have significant effects on saving and may explain some of the differences in saving rates across countries (Jappelli and Pagano 1994). Once households acquire the necessary consumer durables, their saving rates stabilize and even drop slightly.

Prudential AND OTHER BANK Regulations. Prudential and other bank regulations significantly lowered the likelihood of bank failure. This increased security led to larger deposits.

FINANCIAL RESTRAINT. The conventional wisdom is that financial repression depresses saving, particularly deposits in financial institutions. But moderate repression-what this article calls financial restraint-may actually increase saving. Lowering interest rates transfers incomes from households to corporations, and because the corporate sector has a higher propensity to save, aggregate saving increases. This positive redistribution effect is partly offset by the negative interest rate effect: as long as saving responds to changes in interest rates (the interest elasticity of saving is positive), lowering interest rates reduces household saving. But the empirical evidence suggests that this effect is small (see 
Ishikawa 1987 on Japan, Nam 1991 on Korea, and Sun and Liang 1982 on Taiwan, China) and that it is overwhelmed by the redistribution effect (Balassa 1989; Giovannini 1983; Gupta 1984).

Although East Asian economies kept interest rates below equilibrium levels, financial repression was moderate compared with that practiced in many other developing countries with interest rate controls. Average interest rates in East Asia have been moderately negative at worst; many economies in other regions have had highly negative rates (figure 1 ).

The policies associated with financial restraint also increased saving because governments such as Korea's pitted firms against each other to see which could achieve the highest rate of exports and investment. Winners were rewarded with access to cheap credit and the rents associated with other artificially created scarcities. Achieving high rates of investment required high rates of corporate saving. Financial restraint also helped promote household saving by making the financial system more stable. Financial repression (accompanied by entry restrictions) enhanced the profitability-and thus the stability-of financial insti-

Figure 1. Average Real Deposit Rates in Selected Countries, 1978-91

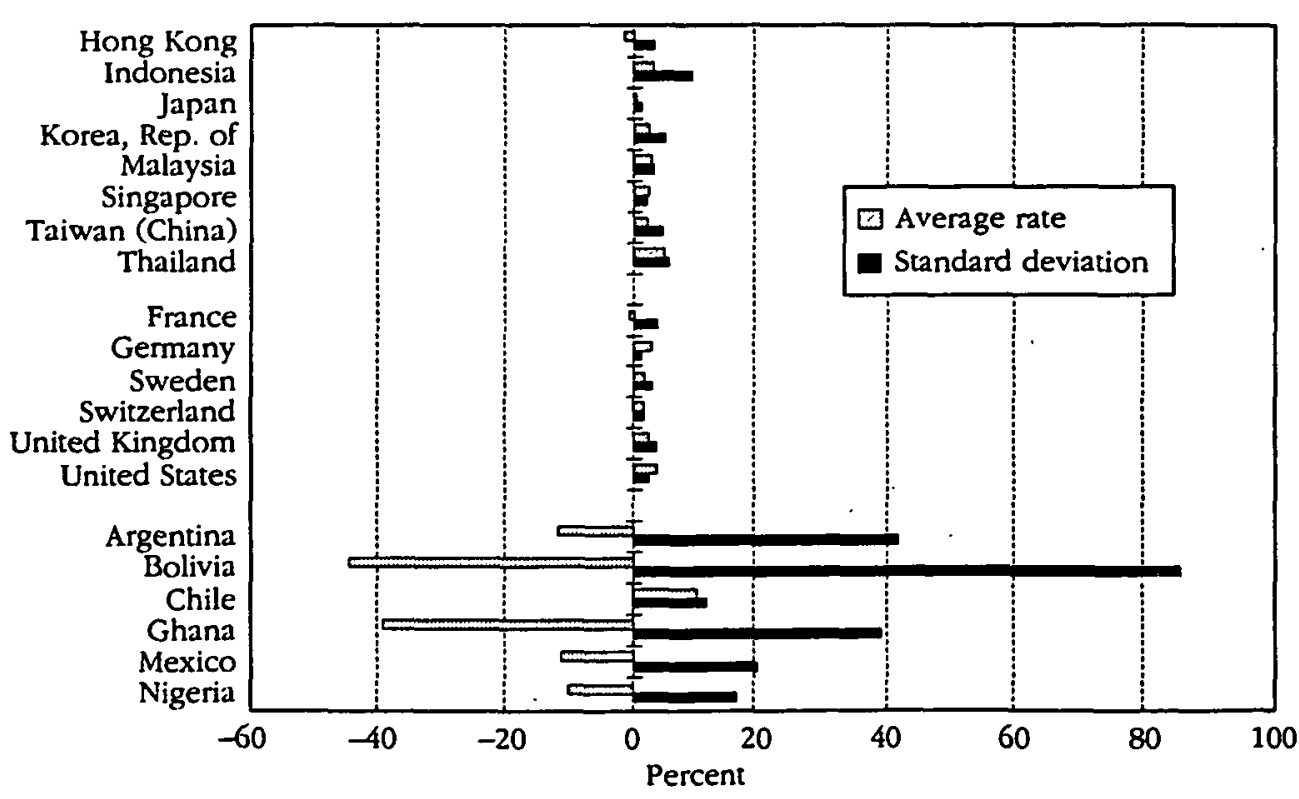

Note: Data for Hong Kong are for 1973-91. Data for Thailand are for 1978-90. Data for Argentina exclude the extreme inflation years of 1984, 1989, and 1990. Data for Bolivia exclude the extreme inflation years of 1985 and 1986. Deposit rates for Ghana are unavailable for 1989 and 1990 and unavailable for Switzerland for 1978-80.

Source: IMF (1995). 
tutions and, by boosting the franchise value of banks, provided strong incentives for banks to undertake prudent investments.

\section{Keeping the Economy Stable and Deficits Low}

Macroeconomic policies in East Asia are far more stable than those in most other developing countries. Macroeconomic stability has a positive effect on saving for a variety of reasons. Because most countries do not have fully indexed accounts, macroeconomic stability, particularly low rates of inflation, reduces the variability of return on saving; a more secure return may increase saving. High and extremely volatile inflation, which often generates large negative real interest rates, is particularly likely to discourage saving. The East Asian economies have generally maintained positive and stable real interest rates on deposits, paralleling interest rate trends in the United States and other industrial countries (see figure 1).

Governments' tendency to run small deficits or large surpluses contributed to macroeconomic stability, and the budgetary surpluses contributed directly to high levels of national saving. All East Asian countries have maintained consistently high public saving as well as growing private saving (figure 2).

\section{Did Interventions Increase Saving Rates?}

That East Asian governments undertook a variety of actions to increase national saving is clear; what is less clear is whether saving rates were higher than they otherwise would have been. Certainly, the region's remarkably high saving rates suggest that government policies had an effect. Studies examining demographic patterns indicate that only part of this difference can be explained using standard life-cycle models. Several authors have emphasized cultural factors in explaining cross-country variations in saving (Horioka 1990). Although these factors may play a role, they do not explain why saving rates were so much higher during the past three decades than in, say, the period before World War II. Surely, entire cultures did not suddenly change.

Rapid growth is one of the distinguishing characteristics of the highperforming East Asian economies. Is it possible that high growth caused high saving, rather than the other way around? Studies have shown a strong correlation between saving and growth (Carroll, Weil, and Summers 1993) and between saving and investment and investment and growth (World Bank 1989). But these correlations do not reveal the direction of causation (nor do they rule out the possibility that other factors are the cause of the observed changes). ${ }^{2} \mathrm{We}$ performed standard tests (called Granger causality tests) to ascertain whether income predicts saving or whether saving more accurately predicts income. The results show income growth to be a better predictor of saving in Indonesia, Japan, Korea, Taiwan (China), and Thailand, but the results were ambiguous for Hong Kong and Malaysia. (In Singapore income growth was not a predictor 
Figure 2. Public and Private Savings in Selected Developing Countries

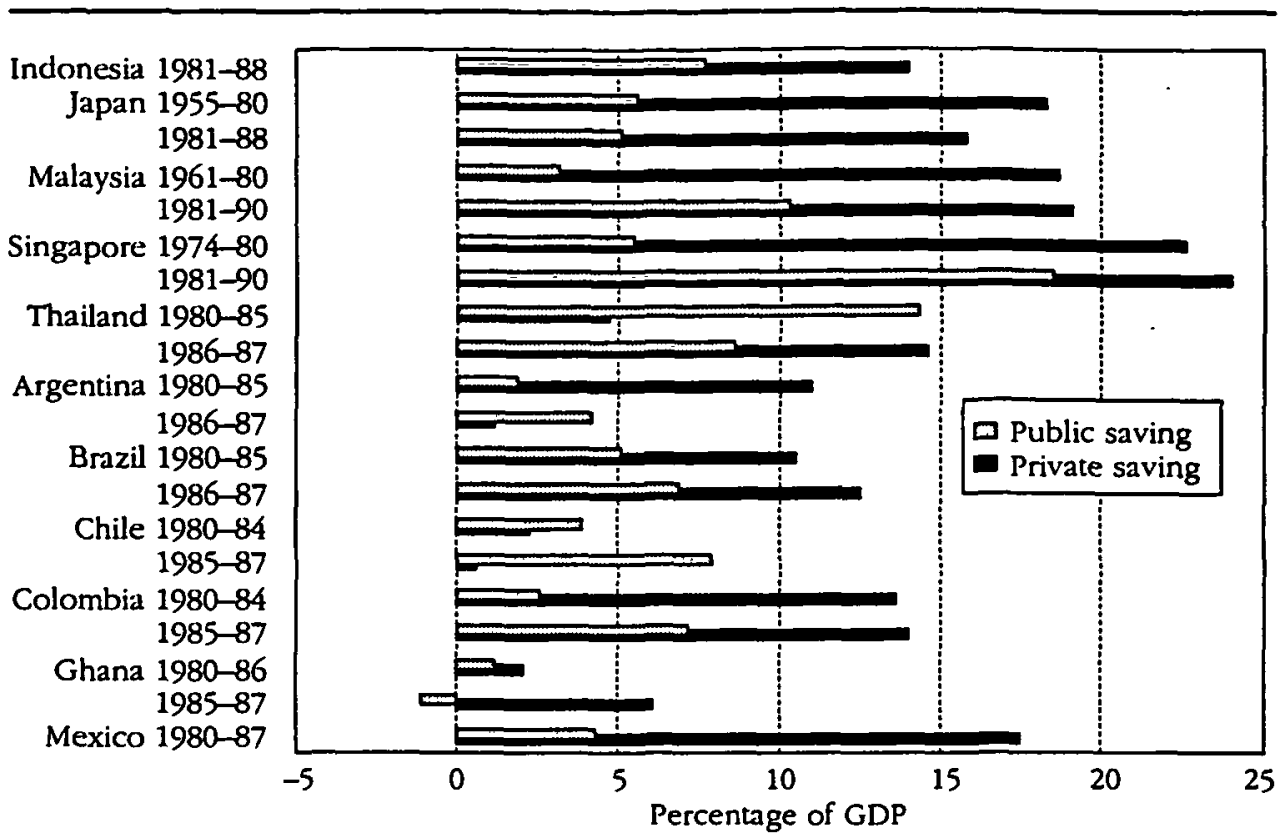

Source: Corbo and Schmidt-Hebbel (1991); Singapore Department of Statistics (various years); Lin (1991); World Bank data; Japanese Economic Planning Agency data.

of the rapid increase in saving rates, a result consistent with a 1991 study by the Monetary Authority of Singapore showing that demographic factors and the policies of the Central Provident Fund accounted for the increase.)

Finding empirical support for a progression from income growth to saving growth is important because it suggests a virtuous cycle in which high growth leads to high saving and high saving leads to high growth. Thus government policies may be able to transform an economy with low income growth and saving to one with high income growth and saving. Moreover, government policies that enhance productive investments and raise income may have a compound effect on growth by increasing saving rates.

Advocates of less government interference in the market claim that such interventions are both ineffective and undesirable. Why interfere with individuals' preferences? There are two broad answers. First, many government interventions represent attempts to remedy market failures, to make markets work better, or to create institutions to fill in gaps left by markets. In particular, the social returns to saving and investment may exceed the private returns, as is the case when there is learning from new investments and the benefits of the learning are not fully appropriable by the investor. Second, saving rates affect the 
intergenerational distribution of income. Markets may yield (Pareto) efficient resource allocations under ideal circumstances, but the distribution of incomeincluding the intergenerational distribution of welfare-yielded by markets is in no way ideal.

\section{Regulating Banks to Enhance Their Solvency}

East Asian governments have imposed several regulations to enhance the solvency of financial institutions, thereby improving both the saving rate and the efficiency of resource allocations. As noted earlier, security is as important to saving as is the rate of interest. Individuals may save even if they have no confidence in any financial institution, but the returns are likely to be lower than could be obtained through a well-functioning financial system. Moreover, wellfunctioning financial institutions are essential to efficient financial intermediation, channeling funds to their most efficient use in an economy.

There is ample evidence that financial crises occur with remarkable frequency in the absence of government intervention. Private monitoring apparently does not suffice to prevent a financial crisis. Moreover, no single financial institution will exercise sufficient care on its own to avoid financial distress. Information failures (individuals may not be able to sort out good banks from bad, for lack of complete information) and credit links among banks mean that the effects of financial failures may spread far beyond an individual bank in distress-there are large negative externalities. These difficulties are exacerbated by the moral hazard problems that arise with undercapitalized financial institutions, because such institutions are more likely to take large risks-they have less to lose if a loan goes bad than better-capitalized institutions. (The market failure rationale for government intervention is treated at length in Stiglitz 1994.)

\section{Prudential Regulations to Keep Financial Institutions Sound}

Japan, Hong Kong, and Singapore began strengthening prudential regulations (sometimes referred to as regulations for safety and soundness) during the 1970s; Malaysia, Taiwan (China), and Thailand followed suit in the 1980s and Indonesia in the 1990s. The stringent regulations common to these economies were adopted for three sets of reasons. Some countries, such as Singapore, recognized the importance of sound prudential regulations early on, not only for their internal capital markets but also for international commerce. Singapore has greatly benefited from its stringent regulations-financial services account for about 17 percent of its gross domestic product. The financial system's size is largely attributable to the confidence of the foreign financial and business community. Even countries that do not aspire to being a regional financial center have recognized that closer links with international markets require that domestic banks meet international standards. 
Other countries imposed such regulations as part of the development process. During early stages governments owned or directly controlled banks and other financial institutions. With development governments gave up direct control. Increased deregulation (of interest rates and entry, for example) reduced governments' leverage on bank behavior, requiring stronger indirect prudential regulation in its place.

Some economies introduced prudential regulations only after experiencing financial difficulties. For example, Hong Kong strengthened its prudential regulations after the financial crises (brought on by real estate speculation) of 1965 and 1985.

Prudential regulation takes a variety of forms, each requiring a different degree of supervision by the regulator. Capital, net worth, and collateral requirements are easiest to monitor, although even they involve some degree of discretion (such as in valuing collateral). At the other extreme is judging the riskiness of particular transactions, which requires the active involvement of bank examiners.

CAPITAL ADEQUACY REQUIREMENTS. Capital adequacy standards are probably the most important tool governments can use to ensure the solvency of financial institutions. These standards make it less likely that liabilities will exceed assets and provide incentives for banks to undertake appropriate risks. The savings and loan debacle in the United States can be partly attributed to the high risks assumed by banks with low or negative net worth. All East Asian economies have adopted the capital adequacy requirements set by the Bank for International Settlements. Most economies had already imposed comparable standards on their own. The one exception is Indonesia, which implemented the new guidelines only recently.

Collateral ReQUiREMENTS. Regulators in East Asia have also encouraged banks to impose sizable collateral requirements to reduce the risks arising from defaults. This practice has earned East Asia's banks the reputation of being "pawnshop" banks. Although collateral requirements will not keep banks solvent, regulators have adopted this conservative system to limit banks' ability to take risks. One unintended impact of this practice has been to tie banks to the fortunes of the real estate market because most collateral has been in the form of real estate. Thus banks have overextended their lending during periods of high asset inflation, exposing themselves to greater portfolio risks during periods of declining asset value: In Japan, for example, the dramatic fall in real estate prices in the first half of the 1990 s created portfolio problems for banks that had engaged in speculative real estate lending during the $1980 \mathrm{~s}$, when asset prices were high.

LENDING RESTRICTIONS. One of the most important objectives of East Asian policymakers was to discourage speculative lending, which has become the main 
source of financial disruptions in Hong Kong, Malaysia, Thailand, and, recently, Japan (table 1). The adverse impact of speculative lending has been aggravated by bank lending to related parties, as bank owners sought to capture the gains from their speculation. In response regulatory authorities have increasingly restricted lending for real estate and to related parties-as well as lending concentrated on a few borrowers. Restrictions on related lending have been difficult to implement, however, because disclosure rules are generally poor, and in Indonesia, Japan, and Thailand, banks and firms have interlinked ownership, and companies are closely held.

DIRECT SUPER VISION. Except in Indonesia, central banks (often working with ministries of finance) in East Asia have done a good job of supervising commercial banks' loan portfolios, resulting in a lower proportion of nonperforming loans than in many other developing countries. Central banks have also supervised bank management, restraining the entry of potentially fraudulent or incompetent lenders. Singapore takes pride in the fact that its regulatory authorities detected problems in the Bank of Credit and Commerce Internationalproblems that escaped detection by allegedly more sophisticated regulators, including those in the United States and United Kingdom-and refused to allow it entry. There are major exceptions to this generally favorable picture of bank supervision, however: the financial difficulties of banks in Hong Kong, Indonesia, Korea, and Malaysia during the 1980 s were brought about in part by weak supervision. Indonesia recently introduced more rigid bank supervision when it liberalized entry for private banks and as the problem of rising nonperforming loans became apparent.

The East Asian style of regulation has, at least uritil recently, been based more on regulatory discretion and constant interaction between regulators and banks than on the more structured rules that characterize supervision in industrial countries. This approach enables regulators to provide banks with feedback on the riskiness of their portfolios. Contemporary supervision practices in most East Asian countries (Japan, Malaysia, and Thailand are good examples) seem to combine modern prudential rules with traditional interactive monitoring, in which supervisors elicit cooperation by using the government's leverage over branch licensing, rediscounts, and other regulations. Although allowing such discretion creates the potential for abuse, abuses do not seem to be prevalent. In other countries, however, this style of regulation could create problems.

PRUDENTIAL BEHAVIOR OF GOVERNMENT BANKS. Unlike government-owned banks in many other developing economies, those in Korea (until their privatization in 1983), Singapore, and Taiwan (China) seem to have behaved prudently. In other countries political considerations often distort the lending decisions of government-owned banks. Many such banks have ended up lending to make up the losses of inefficient public enterprises. And because governments have deep pockets and tend to recapitalize public banks when they run into 
financial trouble, the regulators and managers of publicly owned banks are often less concerned with solvency than private banks are. East Asian governments took several steps to minimize these problems. Taiwan (China) avoided these risks by imposing strict collateral requirements and giving the employees of public banks incentives to act prudently, going so far as to penalize employees whose loans did not perform. Korea imposed strict performance criteria to guide banks' lending decisions. In Malaysia public officials are prohibited from serving on the boards of public banks. But publicly owned banks in Indonesia and a few in Malaysia have not been properly monitored and consequently have experienced high levels of nonperforming loans.

REGULATING NONBANK FINANCLAL INSTITUTIONS. Regulators in East Asia and other developing countries have also been concerned with the appropriate regulation of nonbank financial institutions such as merchant banks, leasing companies, and cooperatives. Since the early 1980 s these institutions have grown in number, but they have been less closely regulated than commercial banks, leading to several major insolvencies (see table 1). For instance, during the first half of the 1980s, Malaysia's deposit-taking cooperatives and Thailand's numerous finance companies became insolvent. These failures threatened the solvency of commercial banks, which often used nonbank financial subsidiaries as a way to avoid close scrutiny by regulators. In response to these insolvencies regulators have increased their supervision of nonbank financial institutions.

\section{Protecting Banks from Competition}

Nearly all governments regulate the entry and operations of financial institutions to ensure that new entrants and incumbents are safe and solvent. But most East Asian governments (with the exceptions of Hong Kong, Singapore, and recently Indonesia) have gone further, restricting entry by new domestic competitors and by foreign banks. As a result few new banks have been established, so the financial sector has expanded largely by licensing new branches of existing banks. Japan's banking system has expanded enormously since the 1950s even though no new banks have been allowed in Japan since then. In Korea and Taiwan (China) only a few new private banks have been licensed in the past few years; competition comes primarily from nonbank financial institutions and the curb market. Not surprisingly, banking in many East Asian economies-Indonesia, Korea, Taiwan (China), and Thailand-has been highly concentrated. Governments had several reasons for imposing entry restrictions.

The most widely cited reasons relate to prudential concerns. Entry restrictions develop from the view that governments must ensure that only trustworthy bankers handle depositors' money. This view is reinforced by the not entirely valid belief that financial systems with a small number of large banks are less risky than systems with a large number of small banks (Vittas 1991). Many policymakers fear that excessively competitive systems-with low profit rates- 


\begin{tabular}{|c|c|c|c|}
\hline Economy & Nature of financial distress & Causes & Nature of bailout or rescue \\
\hline $\begin{array}{l}\text { Hong Kong } \\
1982-83\end{array}$ & $\begin{array}{l}\text { Nineteen deposit-taking } \\
\text { companies failed. }\end{array}$ & $\begin{array}{l}\text { - Large exposure to real } \\
\text { estate lending, fraud and } \\
\text { mismanagement, and weak } \\
\text { prudential regulation. }\end{array}$ & $\begin{array}{l}\text { The government revamped regulatory and } \\
\text { auditing system and liquidated troubled } \\
\text { deposit-taking companies. }\end{array}$ \\
\hline $\begin{array}{l}\text { Hong Kong } \\
1983-86\end{array}$ & $\begin{array}{l}\text { Four banks, including a } \\
\text { major international bank, } \\
\text { became insolvent. }\end{array}$ & $\begin{array}{l}\text { - High international interest } \\
\text { rates. } \\
\text { - Large exposure to real } \\
\text { estate lending and spillover } \\
\text { effects from } 1983 \text { crisis } \\
\text { because these banks owned } \\
\text { deposit-taking companies } \\
\text { as subsidiaries. }\end{array}$ & $\begin{array}{l}\text { The government took over the larger } \\
\text { banks and introduced new management, } \\
\text { including top executives seconded from } \\
\text { the largest commercial bank. Those banks } \\
\text { not taken over by the government } \\
\text { received credit from other commercial } \\
\text { banks. }\end{array}$ \\
\hline $\begin{array}{l}\text { Malaysia } \\
1985-88\end{array}$ & $\begin{array}{l}\text { The failure of one deposit- } \\
\text { taking cooperative in } 1986 \\
\text { caused runs on } 32 \text { (of } 35 \text { ) } \\
\text { others. In addition, } 4 \text { (of } 38 \text { ) } \\
\text { banks and } 4 \text { (of } 47 \text { ) finance } \\
\text { companies were also in } \\
\text { financial distress. Overall, } \\
10.4 \text { percent of banking } \\
\text { system deposits were } \\
\text { affected. }\end{array}$ & $\begin{array}{l}\text { - Fraud and speculation in } \\
\text { real estate and stocks. } \\
\text { - Deterioration in terms of } \\
\text { trade. }\end{array}$ & $\begin{array}{l}\text { The government rescued } 24 \text { insolvent } \\
\text { cooperatives and consolidated and } \\
\text { merged weak finance companies. The } \\
\text { central bank injected fresh equity capital } \\
\text { and replaced management of some banks. }\end{array}$ \\
\hline $\begin{array}{l}\text { Thailand } \\
\text { 1983-87 }\end{array}$ & $\begin{array}{l}\text { Government's cost to bail } \\
\text { out } 50 \text { finance companies } \\
\text { was estimated at US } \$ 190 \\
\text { million, or } 0.48 \text { percent of } \\
\text { GNP. }\end{array}$ & $\begin{array}{l}\text { - Fraud and speculation on } \\
\text { real estate and exchange } \\
\text { rate transactions. }\end{array}$ & $\begin{array}{l}\text { The government liquidated } 24 \text { finance } \\
\text { companies and merged another } 9 \text {, and the } \\
\text { central bank took over the other } 17 \text { and } \\
\text { sold them to new investors (including } \\
\text { other banks). }\end{array}$ \\
\hline
\end{tabular}


Five commercial banks accounting for 24 percent of commercial bank assets were in financial difficulties in 1986-87.

Taiwan (China) 1983-84

\section{Singapore}

Japan

1991
Four trust companies and 11 cooperatives failed.

Domestic commercial bank's nonperforming loans rose to about US $\$ 200$ million, or 0.63 percent of GDP.

A central bank report estimated the size of problem loans of the top 21 banks to be between 3.5 percent and 4.8 percent of banking system assets. Informal estimates of the amount to be written off are as much as 1.5 percent of banking system assets.
- High concentration of unsecured insider loans.

- High international interest rates.

- Cooperatives arbitrating from an artificially steep yield curve.

- Macroeconomic reasons.

- Excessive exposure to real estate lending (90 percent of bad loans), and a steep decline in real estate prices.

- Inadequate prudential supervision. Banks were able to increase their exposure through loans to their nonbank affiliates.
- The government bought some shares of troubled banks.

- To provide emergency loans to troubled banks, the government created a "lifeboat fund" financed by contributions from commercial banks.

- Healthier banks took over management or bought the shares of failed banks.

- The government worked out a two-year write-off period (using tax breaks).

- The government encouraged mergers of weaker banks with healthier ones.

- Groups of banks provided emergency loans to weaker banks.

- Nonperforming loans were to be transferred to a separate financial institution and the cost of the write-offs was to be shared among commercial banks. 
are also excessively fragile. ${ }^{3}$ Restricting competition increases profits, and higher profits strengthen the banking system (provided banks do not simply distribute profits to shareholders). Higher profits also increase a bank's franchise value and its incentive to maintain its reputation, thus encouraging more prudent behavior. Japan's limits on entry appear to have been motivated largely by prudential concerns. From the Meiji era (starting in 1868) until the 1920s, the Japanese banking system was highly unstable-banks were numerous, bank failures (especially of small banks) occurred periodically, and consumer confidence in banks declined. The government responded to a spate of bankruptcies in the 1920 s by encouraging mergers and by regulating banks more closely. Between 1937 and 1940 the number of banks was halved, then halved again through mergers (Dekle 1992). Banks also formed cartels to set interest rates, further boosting their profitability.

The second set of reasons relates to efficiency concerns. Some bank regulators argue that larger (and fewer) banks are more efficient in intermediation. This argument is justified by economies of scale in information gathering and monitoring, but it does not provide a convincing basis for restricting entry. If economies of scale exist, government intervention should not be required to realize them. Besides, protection encourages monopolistic and inefficient practices, undermining the efficiency-enhancing arguments for restricting entry.

A third argument, this one pertaining to entry of foreign banks, is that domestic banks need to be protected until they can compete on an equal basis with established foreign banks. That requires more than just learning banking technology. Savers may have more confidence in foreign banks even if domestic banks are equally efficient in providing services and equally capitalized, putting domestic banks at a competitive disadvantage.

Two factors amplify concerns about foreign entry. The first is that lending patterns may differ as a result of different knowledge. Foreign banks may be more familiar with foreign-owned firms, for example, and may thus exclude domestic firms or charge them higher interest rates. The opposite may be true for domestic banks. Accordingly, the government may want to encourage deposits into domestic banks. The second concern about foreign entry is that domestic banks may be more subject to "window guidance" - that is, they may be more responsive to the monetary authorities' efforts to control money supply through discount rates or reserve requirements.

Entry restrictions are popular because they give governments a powerful discretionary tool for influencing the behavior of banks. Banks have an incentive to respond to government requests lest they forgo the additional profits from asset growth. Because the potential penalties and powers that governments can exercise over domestic banks are greater than those they can exercise over foreign banks, governments have an incentive to restrict the entry of foreign-owned banks. This differential power is reflected in the assertion by some East Asian bankers that they would not mind the entry of foreign banks if the banks competed on a level playing field. In their view the demands government puts on 
them-which it cannot put on foreign banks-puts them at a disadvantage. East Asian governments have exerted influence over domestic banks not only in the level of lending (as is common in industrial countries) but also in the direction of lending-toward investments where social returns are viewed as being particularly high.

These governments have attempted to balance the advantages of competition (greater efficiency) with the perceived disadvantages (loss of discretionary power and lower profits, perhaps leading to less stable financial institutions). In some cases governments have been able to strike a reasonable balance. The enhanced stability of the financial system as a result of entry restrictions led to financial deepening, while the cost of the reduced competition was reflected more in reduced innovation than in higher lending margins or spreads. ${ }^{4}$ And there is considerable evidence that governments were able to guide the allocation of credit, partly as a result of their discretionary powers (for example, with respect to branch banking).

\section{Creating Development Banks and Financial Markets to Fill Credit Gaps}

During the past few decades East Asian governments have helped develop financial markets by creating financial institutions to fill gaps in the types of credit private entities provide. Most countries have established long-term credit banks and specialized institutions providing credit for agriculture, small firms, and housing. Some East Asian governments have also established commercial banks that cater to a specific group of borrowers (such as Malays or the Islamic community). Here we focus on development banks.

Banks offering long-term credit have been among the most common government-created financial institutions. The Japanese government created the Industrial Bank of Japan in 1902 in part because of the absence of alternative sources of long-term credit for business investment (such as bond and equity markets). The government also recognized that commercial banks were poorly suited to extending long-term credit.

Why did the government choose to create long-term credit banks instead of trying to create securities markets? Some observers have emphasized the key advantages that banks have over markets, advantages that are particularly important at early stages of development. Most important, banks have the institutional capacity and incentives to monitor business borrowers closely; such monitoring becomes critical when there is no well-developed industry of financial analysts. Close supervision is needed to assess when to extend and when to withdraw credit and to distinguish between situations where profits are low because of bad luck or an economic downturn and those where they are low because of bad management. Without such close supervision, the banks might be reluctant to take on risk and might focus on short-term profits instead. 
Governments set up long-term credit institutions rather than lending or investing directly in firms largely because they believed that a certain amount of independence would enhance the performance of banks and firms. Long-term investments require selection and monitoring. Government agencies are not designed to screen and monitor commercial projects and might be subject to political influence. The creation of the Industrial Bank of Japan reflected a recognition that long-term credit banks had served as effective monitors of firms in other countries, especially among firms not affiliated with major conglomerates (Packer 1992).

\section{Relationship of Development Banks with Government}

Governments did more than create the development banks. They also provided assistance, particularly in developing sources of funds during the banks' early years. For example, the Japanese government initially bought a substantial share of the bonds issued by private long-term credit banks and was a catalyst in ensuring that other private banks and financial institutions subscribed to these bonds. It allowed development banks to issue long-term bonds or debentures, whose market the government helped create. This privilege helped redress the mismatch between the maturity structure of the banks' assets and their liabilities, a problem that had plagued commercial banks. Limiting competition enabled the long-term credit banks to obtain funds more cheaply than they otherwise could have. The government went even further, encouraging government units and commercial banks to purchase the long-term bonds, which allowed the development banks to obtain funds at an even lower rate. The Thai government provided similar privileges to its private long-term credit banks.

Why do governments form both public and private development banks? The main advantage of private development banks is that they are further removed from government, although the government can still exercise considerable influence. The Industrial Bank of Japan, for example, could choose projects according to its own commercial criteria, but it had to select firms from within priority industries identified by the government. There are tradeoffs: the closer the link between banks and the government, the easier it is for the government to exercise influence and the less likely it is that commercial criteria will be employed. Private development banks may be more credible in setting commercial criteria for investment projects, but private ownership places an additional monitoring burden on government to guard against misappropriation of government assistance. Japan's private and public development banks illustrate how lending activities are divided. The privately owned Industrial Bank is a major lender of long-term funds to industries that are not necessarily being promoted by government, and it has acquired a substantial reputation within these industries. The government-owned Japan Development Bank, on the other hand, focuses its lending on industrial activities that have received the highest subsidies, such as sea transport, mining, electric power, and transport machinery. 


\section{The Influence of Development Banks}

Development banks lent substantial funds on a long-term basis in Indonesia, Japan, Korea, and Taiwan (China), but not in Hong Kong, which has no development banks, or Thailand, where industrial development banks hold only 1 percent of the assets of the financial system. The Korean Development Bank accounted for about a third of all loans and guarantees in the 1970s. Taiwan's Bank of Communications accounts for about half the assets of the banking system. In Japan the development banks together accounted for about two-thirds of outstanding loans for equipment investment in the 1950s and about half in the early 1960s. The Japan Development Bank alone accounted for 45 percent of equipment lending in the early 1950s. Since the 1950s, however, the Japan Development Bank's lending has accounted for only 2 percent of newly lent funds (Kawaura 1991; Horiuchi and Sui 1993). In recent years the share of development lending has been small even in new growth industries.

DEVELOPMENT LENDING AS A COMPLEMENT TO COMMERCIAL LENDING. For Several reasons, however, development banks have been more influential than their small share in lending might suggest. Because they had close ties to the government, their lending provided information to entrepreneurs and other banks on the areas that the government was promoting. In addition, other financial institutions valued information on the development banks' choice of clients (as distinct from sectors). This signaling effect works, of course, only if development banks have sound institutional reputations, which they did in Japan, Singapore, Taiwan (China), and, by and large, Korea.

Development banks did more than provide information. They also initiated loan syndication and other forms of cooperative lending with private banks. Development bank lending often created the perception of "risk sharing"-government support made it more likely that government assistance would be forthcoming in the event of a problem (Yasuda 1992). The perception of implicit government insurance of priority activities was fortified by several government bailouts within priority sectors. At the government's urging, the Industrial Bank of Japan led syndications for firms in distress and forced their restructuring to avoid liquidation or external takeovers. In Indonesia the government bought 35 percent of the equity of a large cement plant, a priority activity, when the plant became financially troubled (Kunio 1988). To protect firms and banks, Korea extended cheap loans during the 1980 s to firms that were unable to meet their debt obligations.

Thus development lending complemented private sector lending rather than displaced it. To see how the Japan Development Bank's lending to medium-size and large firms affected corporate investment, Horiuchi and Sui (1993) analyzed a sample of 477 medium-size firms listed in the Tokyo Exchange in 1965. They found that an increase in a Japan Development Bank loan to a firm induced more than an equal increase in the firm's investment spending. Moreover, 
private banks extended credit more actively to firms that borrowed from the development bank than to those that did not. Japan Development Bank loans preceded the increase in a firm's borrowing from private banks, further evidence of the signaling effect. Japan Development Bank borrowers also enjoyed more favorable borrowing conditions from other banks and were less sensitive to changes in the cost of capital than were firms that did not borrow from Japan Development Bank.

Even private long-term credit banks seemed to follow the lead of the public development banks. Of 161 listed companies that had a private long-term credit bank as its primary lender in 1967, nearly half also obtained loans from the Japan Development Bank, and 20 percent obtained loans from the ExportImport Bank of Japan.

Establishing a causal link between development bank and commercial bank lending is difficult, but several pieces of evidence support the existence of such a link, beyond the evidence on timing noted earlier. Incentives for cooperative financing between Japanese development banks and commercial banks were strong, for example. Commercial banks that cofinanced projects initiated by the long-term credit banks received preferential treatment in purchasing the financial debentures issued by the long-term credit banks.

That development banks influenced lending is important, of course, only if their lending patterns differed from those that commercial banks would have chosen on their own. There is evidence that this is the case. As noted earlier, the discrepancies between private and social returns may be large. Even if such discrepancies did not exist, however, governments believed that they did and expected substantial gains from channeling resources to priority areas where social returns exceeded private returns. Development banks were one of their main tools for channeling such resources. Priority sectors varied across countries and over time. Most countries gave some priority to exports; the Korean Development Bank was a major financial intermediary for loans to heavy and chemical industries in the 1970s, and both the Bank of Communications in Taiwan (China) and Singapore's Development Bank have been active in financing high technology.

SPECIALIZED DEVELOPMENT BANKS. Most East Asian governments have also created specialized banks in areas where private lending has been viewed as inadequate, most notably in agriculture and small-scale enterprises. Thailand's agricultural development bank, for example, caters to small farmers who do not have access to commercial bank lending. The bank has reached 80 percent of potential agricultural borrowers (including most small farmers), even though its lending to agriculture is much smaller than total commercial bank lending. Loan rates are slightly lower than commercial bank rates and substantially lower than informal market rates. The bank operates on a cost plus basis (over subsidized funds) and has prudently reduced lending in response to nonrepayment. The bank has been financially sound despite high operating costs and the expected 
poor repayment record. To increase farmers' access to formal credit, the Thai government has complemented financial reforms with legal reforms that enable small farmers to use their land as collateral for loans.

Because markets for mortgages-especially for low-income housing-are underdeveloped, East Asian governments have also created financial institutions for housing finance. Japan's postwar government created the Housing Corporation, whose lending has accounted for a growing share of the government's fiscal investment and lending program. Singapore is probably the most prominent example of intervention in housing finance. In 1960 the government established the Housing Development Board to build and provide subsidized mass housing, which policymakers viewed as essential to maintaining social stability. The government subsequently allowed would-be buyers to use part of their provident fund contributions to purchase the subsidized housing. The housing subsidies may have resulted in lower wages (particularly in a country such as Singapore, where wages are determined through national bargaining), but the lower wages boosted profits and, consequently, retained earnings. Moreover, the housing program increased social stability by raising living standards and increasing the net worth of households, giving them a greater financial stake in their society.

\section{Why Have Development Banks Succeeded in East Asia?}

Many developing countries have been unsuccessful in promoting development banks. Eighteen development banks examined in a World Bank (1989) study had, on average, half of their loans in arrears. Even in East Asia, where the experience with development banks has been mostly positive, development banks have failed. Japan's insolvent Reconstruction Finance Bureau was closed in 1952 and Thailand's Industrial Bank in 1959. Some development banks in Indonesia and Malaysia are reporting a rising volume of arrears. The most common causes of failure are political pressure to finance bad projects and poor incentives for financial institutions to screen and monitor projects.

Among the key ingredients of the success of many other East Asian development banks was an insistence on commercial standards within the priority sectors. Successful development banks transformed themselves from government agencies financing development projects into more market-oriented financial enterprises. The largest development banks of Japan, Korea, Singapore, and Taiwan (China) have consistently demonstrated such a pattern.

Although government monitoring seems to have had a salutary effect in East Asia (Cho and Hellman 1993), government intervention has had a negative impact in other countries. This differentiated outcome is likely the result of government efforts to shield development banks from political interference. Japan, Korea, and Taiwan (China) appointed established officials (from ministries of finance) as chairmen so that they could better withstand pressure from other parts of the government. That does not explain why these officials did not subvert the development banks for their own purposes, however. And the fact that 
these officials were competent and honest does not mean that in other countries and at other times oversight by a ministry of finance will provide an adequate check against abuse. Some East Asian countries have also controlled types of lending: Thailand simply barred its development bank from lending to state enterprises. Successful development banks also instilled a high level of professionalism and institutional identification in their staff, making government intervention-other than in establishing priority sectors-difficult. By making lending to a nonperformer a criminal offense, Taiwan (China) made sure that loan officers did not give in to political pressures or abuse their discretion. Moreover, private banks often cofinanced development bank projects, thereby serving as a check on development banks' lending criteria. Thus the information flow between development banks and commercial banks was reciprocal.

\section{Creating Financial Markets}

Only a small portion of long-term investments in East Asia have been financed by corporate bonds. Except for Thailand and Korea since 1980, bonds accounted for much less than 10 percent of the net financing of nonfinancial corporations among five high-performing East Asian economies for which data exist (World Bank 1993a). One obstacle to the emergence of bond markets in these economies is the absence of a market for government securities-because the governments do not run deficits, they do not need to borrow. With no market for government securities, there is no benchmark risk-free rate, and so markets must determine both the risk-free rate and the risk premium associated with a specific corporate bond. Hong Kong's government has responded to this limitation by auctioning government bonds-even though it does not need the financing - to provide a benchmark risk-free rate and eventually help create a market for corporate bonds. Malaysia and Singapore are considering doing the same.

Other East Asian economies have also taken steps to foster the growth of bond markets. Malaysia, for example, established a rating agency for bond issues in 1991. Hong Kong, Taiwan (China), and Thailand have strengthened their legal infrastructure for securities (bonds and equity) issues. And in Korea-which has the region's most rapidly expanding bond market-the government has been issuing guarantees.

Like bond markets, equity markets provide a small fraction of the net financing of nonfinancial corporations in East Asia, although the relative importance of equities rose slightly in Korea and Thailand during the 1980 s. In recent years East Asian governments have increased their efforts to promote stock markets. Hong Kong has strengthened disclosure requirements and implemented laws against fraud in response to financial disruptions experienced in the stock exchange. Korea, Taiwan (China), and Thailand have provided preferential corporate tax measures to encourage companies to list on the stock exchange. Korea introduced these incentives in the 1970 s and since the 1980 s has indirectly 
promoted equity issues by encouraging firms to lower their debt-equity ratios. All of these East Asian economies have expanded their stock exchanges; Indonesia, Korea, and Singapore have introduced over-the-counter markets.

\section{Enhancing Growth through Financial Restraint and Credit Allocation}

Earlier we showed how, contrary to standard arguments, financial restraint may have increased national savings. A standard argument against financial restraint has been that it impedes efficient resource allocation by preventing a free market auction from occurring (World Bank 1989; Fry 1988). As recent work on credit markets has emphasized, however, credit is not allocated by auction even in perfectly competitive markets. In a world of asymmetric information, banks do not allocate loans to the highest bidders, but rather to those borrowers they deem most likely to repay. Even when the adverse selection and incentive effects associated with higher interest rates do not induce credit rationing (Stiglitz and Weiss 1981), these effects do mean that moderate financial restraint on lending rates reduces default rates and increases the social returns to lending.

Financial restraint has further allocative benefits. To the extent that lower deposit rates are reflected in lower lending rates, financial restraint enhances the ability of firms to increase their equity, and hence their level of investment and their ability and willingness to take prudent risks (Stiglitz 1994). To the extent that lower deposit rates are not passed on in lower lending rates, financial restraint enhances bank equity, and hence banks' ability and willingness to make loans. And greater bank equity enhances the stability of the financial system. One of the benefits of stable financial systems is the organization-specific nature of information: bank failures destroy information that is valuable to ensuring the efficient allocation of capital.

Financial restraint also has incentive effects. Higher bank profits increase the franchise value of banks, providing strong incentives for prudential behavior. Appropriately chosen bases for allocating scarce credit can also provide strong performance incentives. In Japan, Korea, and Taiwan (China), competition for access to credit generated high marginal returns to greater effort, as measured, for instance, by exports (Stiglitz 1994). Because the shadow value of access to capital was high, this prize was valuable.

The empirical evidence usually cited against financial restraint, based on crosscountry regressions showing a positive relation between real interest rates and output growth (Gelb 1989), is as faulty as the theoretical arguments. This evidence suggests that high real interest rates are associated with increased financial depth, a modest increase in savings and investment, and more productive investments (World Bank 1989). That savings and income have continued to grow in East Asian countries despite financial restraint raises some questions 
about the findings of these studies: does anyone really believe growth would have been even faster in East Asia in the absence of financial restraint?

There are three problems with these studies (see Stiglitz 1994 and Murdock and Stiglitz 1993 for greater detail). First, they fail to distinguish between large and moderate degrees of interest rate constraints. Highly negative real rates have a severely negative impact on economic performance, which the regressions capture, but moderate interest rate restraints may yield positive effects, which the regressions do not reflect. Indeed, when the sample is split between developing countries with high and those with moderate degrees of financial repression, the positive correlation between real interest rates and growth disappears for the countries with moderate financial restraint.

Second, countries with severely negative real interest rates have had both severe financial repression and bad macroeconomic policies (as reflected in high rates of inflation). These policies, rather than the financial restraint, may account for their poor economic performance. That suggests that the gains to growth come less from rationalizing interest rates and more from decreasing the distortionary effects of high inflation.

The third problem is one of identification: real interest rates may be low not because of financial restraint, but because there are no good investment opportunities. This problem can be addressed in two ways: using a simultaneous equations model or trying to measure financial restraint directly. Such assessments are possible for Korea and Taiwan (China), using data on curb market rates. For these cases the degree of financial restraint does not appear to explain economic growth, although other variables, such as inflation, do.

\section{Priorities Reflected through Directed Credit}

All East Asian countries have directed credit in varying degrees to support industrial policies or social objectives. Countries direct credit for several reasons, ranging from a perceived contrast between social and private economic rates of return to more immediate concerns, such as providing national security. Like other economies, high-performing East Asian economies use two broad types of intervention. First, the government directs credit to priority firms, groups, industries, and activities (such as exports or high-technology projects). Second, the government directs credit for social reasons, often to small farmers, small and medium-scale enterprises, or a specific ethnic group. In both cases the government directs credit by investing in public enterprises, using its development banks to lend to priority areas (and to signal to other financial institutions what these areas are), and compelling commercial banks to lend to designated activities. Although the rationale for and categories of directed credit do not differ between the East Asian economies and other economies that have used directed credit, the high performers in East Asia have implemented their programs with more moderate credit subsidies and with institutions that enabled better selec- 
tion (through performance criteria) and monitoring of promoted projects, resulting in higher repayment rates for subsidized loans.

Among East Asian economies Japan and Korea most pervasively directed credit to promote specific firms and industries-Japan during its postwar reconstruction and Korea during its promotion of chemical and heavy industries in the 1970s. During the 1950s the Japanese government's financing amounted to nearly a third of new equipment lending to industry; most went to shipbuilding, electrical power, coal, sea transport, and machinery. The results of the program in Japan are controversial: many successful growth industries were not heavily supported by the government's credit programs; among those provided with credit subsidies, some (such as shipbuilding) increased their exports, while others (such as coal mining) continued to decline. The results of Koreas's policy loans also have been mixed (Stern and others 1992). Some of Korea's heavy industries, such as steel, electronics, and passenger cars, became leading exporters during the 1980 s, while others became financially distressed. The chemical and heavy industries policies also increased the concentration of wealth among conglomerates and contributed to high firm leverage (Cho and Kim 1995).

Indonesia and Malaysia had few successful experiences with selective credit intervention and abandoned the schemes once the negative effects of the policy became apparent. Thailand has avoided credit programs directed at specific firms and industries.

Assessing the success or failure of a directed credit program is difficult for three reasons. First, as mentioned earlier, there is usually no way of knowing whether growth would have been higher or lower in the absence of the directed credit program. Second, a good program requires risk-taking, which means that failures are inevitable. A program with nothing but successes would necessarily have been too conservative. Third, many of the returns may be long term, so current profitability may not provide an adequate measure of success. Thus the measure of Korea's chemical and heavy industry program should not be how those industries fared in the early 1980s, but what the structure of the economy looks like in the late 1990 s. By the same token, low profits may reflect cyclical conditions rather than long-run prospects.

Thus, although it is difficult to determine whether directed credit programs were successful, the evidence shows that government lending did not simply displace private lending -it affected the allocation of resources. Moreover, credit was directed to areas with high social returns. During the 1950s in Japan, for instance, the bulk of directed credit went to basic industries that supplied essential inputs for growth in other parts of the economy. Once these basic industries were developed, Japan promoted other industries (such as machine tools) whose expected spillover effects on the economy were large (JDB/JERI 1993).

Many other developing countries have failed in their industrial credit programs. At least six factors set the successful East Asian economies apart from others. First was their ability to change credit policies rapidly when they real- 
ized the policies were not functioning properly. Second, unlike many developing countries that funneled a large portion of directed credit to public enterprises, the high-performing East Asian economies directed credit mainly to private enterprises. Even in East Asian countries that made loans to state-owned firmsIndonesia, Malaysia, and Singapore-the proportions of total credit were not persistently high, the state firms tended to perform better financially than state firms in other countries, and the interest rate subsidies were not substantial (except in Indonesia). Third, all East Asian economies directed credit to industry based on broad functional criteria (such as whether the firm produced exports), typically using objective performance measures. Fourth, credit was usually more common than outright subsidies, which were limited. Fifth, directed credit was more limited than elsewhere. Although directed credit amounts to as much as 75 percent of the loans of financial institutions in some countries, even in Korea (which used directed credit most aggressively) directed credit amounted to only about 40 percent of total credit, and in Japan it never exceeded 15 percent. Sixth, monitoring was more effective, so default rates were lower.

\section{Can the East Asian Experience Be Replicated?}

Most East Asian governments' financial sector interventions were meant to remedy market failures. Such failures occur even in industrial countries, and governments impose extensive regulation to deal with them. Market failures are usually more significant in developing countries, and governments' ability to correct them is more circumscribed. What is remarkable is that East Asian governments undertook actions (such as prudential regulation) similar to those taken by more industrial countries, and that they did so at an earlier stage of development. Moreover, these regulatory initiatives succeeded without the abuses that often accompany them elsewhere. East Asian governments sought not to replace markets and market forces, but to use and direct them. Government lending programs complemented private lending; they did not replace or displace it. Although governments established priorities for lending-and discouraged lending for real estate and consumer goods-they still employed commercial standards.

How replicable are these interventions in other developing countries? That so many East Asian economies were successful suggests that success was not just fortuitous, the result of, say, unusually good civil servants. The cultural diversity of the region makes explanations based on unique cultural factors unpersuasive (Stiglitz 1994).

Many of the specific institutions, programs, and practices that contributed to East Asia's success can easily be replicated, including the region's large investment in education. The resultant high level of educational attainment undoubtedly contributed to governments' ability to execute their programs. Several of the institutions that contributed to high savings-such as the postal saving system and provident funds-could easily be introduced elsewhere. Prudential regu- 
lations, particularly capital adequacy requirements and controls on real estate lending, are essential and replicable. The adaptability of government policiesthe ability to abandon policies when they fail and to change policies with changing circumstances-is clearly a lesson of general applicability, although it is hard to design institutions that capture that lesson.

The main concern with activist policies such as those pursued in East Asia is abuse of political power: activist policies generally entail giving governments discretionary powers that can easily be abused. In other countries such abuse explains or at least contributes to the failure of activist programs. But many of the ways in which East Asian institutions were designed reduced their vulnerability to political abuse-and these institutional arrangements can be replicated. The use of performance-based criteria for allocating credit, for example, limited discretion. Similarly, requiring that commercial criteria be satisfied to receive credit and requiring borrowers to raise part of their funds on their own and to put up their own equity are replicable practices that enhance the likelihood that funds will be allocated to good ventures and reduce the likelihood of political abuse.

Furthermore, moderate subsidies and financial restraint reduced rents (relative to those found in many developing countries), further attenuating incentives for abuse. So did the extensive use of competition (Stiglitz 1994). Japan used several tools, including interest rate regulation and competition from nonbank financial institutions, to curtail potentially high rents from entry restrictions.

At bottom, however, is a more fundamental issue: why were the governments of East Asia able to implement policies that lessened the potential for abuse? The answer lies in political economy, which is beyond the scope of this article. A few studies have touched on this issue (Campos 1993), but much remains to be done.

\section{Notes}

Joseph E. Stiglitz is chairman of President Clinton's Council of Economic Advisers, on leave from Stanford University, where he is professor of economics, and Marilou Uy is with the South Asia Country Department of the World Bank. This article was written as part of the World Bank's project on the East Asian miracle. The views expressed in it are solely those of the authors and in no way represent those of the organizations with which they are affiliated. The authors gratefully acknowledge the research assistance of Kevin Murdock, as well as the comments of participants at the many seminars at which portions of this article were presented. The authors also acknowledge the assistance of Brian Casabianca in preparing the figures.

1. Many of the theoretical and technical details of the analysis presented in this article, especially on the market failure framework, are discussed in Stiglitz $(1985,1989,1994$, and 1996) and Greenwald and Stiglitz (1986).

2. Standard economic theories have identified several reasons why savings rates might depend in part on income growth rates (Carroll, Weil, and Summers 1993), although the sign of the relationship is ambiguous. First, as growth rates increase, households become less confident that such growth will be sustained; it becomes more probable that growth 
will fall, and so individuals are induced to put away more for a "rainy day." Second, as growth rates increase, the degree of uncertainty increases, which may induce households to save more. Third, at higher growth rates, the return to capital may be higher, and higher returns to capital may elicit higher savings rates. And fourth, lags in adjustment (habit formation) may result in consumption not keeping up with income. That is perhaps the most persuasive reason for the high savings rate. Other arguments suggest that faster growth rates would be associated with lower savings rates. With higher growth rates, individuals need to save less for the future.

3. To be sure, in a world with perfect information, depositors would recognize the risks associated with undercapitalized and low-profit banks and would deposit their money with such institurions only if the higher rate of interest paid on deposits compensated for the risk. These higher required deposit rates would serve as a barrier to entry, ensuring that even without government intervention there would not be "excessive" entry; evidence for this exists for some countries. Still, in many of the countries of East Asia, it appears that-at least at their stage of development-there would have been far more entry in the absence of government intervention.

4. Even with entry restrictions, competition remained keen in most East Asian countries (for Japan, see Sakakibara, Feldman, and Harada 1982): Japanese banks have lower margins than banks in the United States (Ueda 1992) or Germany. Gross interest markups as well as net operating costs (as a percentage of total assets) of banks in Korea, Malaysia, and Thailand were in line with those in industrial countries in the early 1980s and lower than in many other developing countries, notably Turkey and selected countries in Latin America (Hanson and Rocha 1986). On the other hand, World Bank studies (World Bank $1993 \mathrm{~b})$ of the banking systems in Indonesia and Korea find that protection has led to less efficient and innovative practices. Moreover, even in Japan there has been less innovation than in the United States, for example, in introducing derivative securities.

\section{References}

The word "processed" describes informally reproduced works that may not be commonly available through library systems.

Balassa, Bela. 1989. "The Effects of Interest Rates on Savings in Developing Countries." Policy Research Working Paper 56. World Bank, Policy Research Department, Washington, D.C. Processed.

Campos, Jose Edgardo. 1993. "The Institutional Foundations of High-Speed Growth in the High-Performing Asian Economies: Insulation Mechanisms and Public SectorPrivate Sector Relations." Background paper for The East Asian Miracle. World Bank, Policy Research Department, Washington, D.C. Processed.

Carroll, Chris, David N. Weil, and Lawrence H. Summers. 1993. "Savings and Growth." Paper presented at the Bradley Policy Research Center's Carnegie-Rochester Public Policy Conference, Rochester, N.Y. Processed.

Chiu, Paul C. H. 1992. "Money and Financial Markets: The Domestic Perspective." In Gustav Ranis, ed., Taiwan from Developing to Mature Economy. Boulder, Colo.: Westview Press.

Cho, Yoon Jee, and T. Hellman. 1993. "Government Intervention in Credit Markets: An' Alternative Interpretation of Japanese and Korean Experiences from the New Institutional Economics Perspective." World Bank, Financial Sector Department, Washington, D.C. Processed.

Cho, Yoon Jee, and Joon-Kyung Kim. 1995. Credit Policies and the Industrialization of Korea. World Bank Discussion Paper 286. Washington, D.C.

Corbo, Vittorio, and Klaus Schmidt-Hebbel. 1991. "Public Policy and Savings in Developing Countries." Journal of Development Economics 36(1):89-115. 
Dekle, Robert. 1990. "Do the Japanese Elderly Reduce Their Total Wealth?" Journal of the Japanese and International Economies 4(September):309-17.

- 1992. "Raising Saving Rates: Lessons from Japanese Experience." Background paper for The East Asian Miracle. World Bank, Policy Research Department, Washington, D.C. Processed.

Fry, Maxwell J. 1988. Money, Interest, and Banking in Economic Development. Baltimore, Md.: Johns Hopkins University Press.

Gelb, Alan. 1989. "Financial Policies, Growth, and Efficiency." Policy Research Working Paper 202. World Bank, Policy Research Department, Washington, D.C. Processed.

Giovannini, Alberto. 1983. "The Interest Elasticity of Savings in Developing Countries: The Existing Evidence." World Development 11(7):601-7.

Greenwald, Bruce, and Joseph E. Stiglitz. 1986. "Externalities in Economies with Imperfect Information and Incomplete Markets." Quarterly Journal of Economics 101(2):22964.

Gupra, Kanhaya L. 1984. Finance and Economic Growth in Developing Countries. London: Croom Helm.

Hanson, James, and Roberto Rocha. 1986. "High Interest Rates, Spreads, and the Costs of Intermediation: Two Studies." Industry and Finance Series 8. World Bank, Washington, D.C. Processed.

Horioka, Charles Y. 1990. "Why Is Japan's Household Saving Rate So High? A Literature Survey." Journal of the Japanese and International Economies 4(March):49-92.

Horiuchi, Akiyoshi, and Qing-yuan Sui. 1993. "The Influence of the Japan Development Bank Loans on Corporate Investment Behavior." Journal of the Japanese and International Economies 7(December):441-65.

IMF (International Monetary Fund). 1995. International Financial Statistics. Washington, D.C.

Ishikawa, T. 1987. "Savings: Structural Determinants of Household Saving and the Financial and Tax Systems." In K. Hamada, M. Kuroda, and A. Horiuchi, eds., Macroeconomic Analysis of the Japanese Firm. Amsterdam: North-Holland.

JDB/JERI (Japan Development Bank and Japan Economic Research Institute). 1993. "PolicyBased Finance. The Experience of Postwar Japan, Final Report for the World Bank." Tokyo. Processed.

Jappelli, Tullio, and Marco Pagano. 1994. "Saving, Growth, and Liquidity Constraints." Quarterly Journal of Economics 109(February):83-109.

Kawaura, Akihiko. 1991. "Identification of the Size and Direction of the Post-War Credit Allocation in Japan." World Bank, Financial Sector Development Department, Washington, D.C. Processed.

Kunio, Yoshihara. 1988. The Rise of Ersatz Capitalism in South East Asia. New York: Oxford University Press.

Lin, See Yan. 1991. "Savings Investment Gap, Financing Needs, and Capital Market Development." Bank Negara Malaysia, Kuala Lumpur. Processed.

Monetary Authority of Singapore. 1991. "Savings-Investments Balances in Singapore: Determinants and Medium-Term Outlook." Economics Department, Singapore. Processed.

Mukai, Yurio. 1963. "Development of Postal Savings and Its Factors" (in Japanese). Kinyu Keizai 83(December).

Murdock, Kevin, and Joseph E. Stiglitz. 1993. "The Effect of Financial Repression in Economies with Positive Real Rates: Theory and Evidence." Background paper for The East Asian Miracle. World Bank, Policy Research Department, Washington, D.C. Processed.

Nam, Sang-Woo. 1991. “Korea's Financial Policy and Its Consequences." Paper presented at the East-West Center's Workshop on Government, Financial Systems, and Economic 
Development: A Comparative Study of Selected Asian and Latin American Countries, Honolulu. October. Processed.

Noguchi, Y. 1985. "Pensions, the Tax System and the Saving Behavior of the People." In Kenkyu Hopoku Gaiyo [Summary of Research Findings]. Research Project on the Future Prospects of Government-Managed Voluntary Life Insurance, Tokyo. (In Japanese.)

Packer, Frank. 1992. "The Role of Long-Term Credit Banks within the Japanese Main Bank System." Columbia University, New York. Processed.

Sakakibara, E., R. Feldman, and Y. Harada. 1982. The Japanese Financial System in Comparative Perspective. Washington, D.C.: U.S. Government Printing Office.

Shea, J. D. 1993. "Development and Structural Change of the Financial System." In Patrick Hugh and Yung Chul Park, eds., Financial Development-Japan, Korea and Taiwan. New York: Oxford University Press.

Singapore Department of Statistics. Various years. Yearbook of Statistics. Singapore.

Stern, Joseph, Ji-Hong Kim, Dwight Perkins, and Jung-Ho Yoo. 1992. "Industrialization and the State: The Korean Heavy and Chemical Industry Drive." Harvard Institute for International Development, Cambridge, Mass., and Korea Development Institute, Seoul. Processed.

Stiglitz, Joseph E. 1985. "Credit Markets and the Control of Capital." Journal of Money, Credit, and Banking 17:133-52.

1989. "The Economic Role of the State." In Arnold Heertje, ed., The Economic Role of the State. Oxford, U.K.: Basil Blackwell.

1994. "The Role of the State in Financial Markets." In Michael Bruno and Boris Pleskovic, eds., Proceedings of the World Bank Annual Conference on Development Economics 1993. Washington, D.C.: World Bank.

. 1996. "Some Lessons from the East Asian Miracle." World Bank Research Observer 11(2):151-77.

Stiglitz, Joseph E., and A. Weiss. 1981. "Credit Rationing in Markets with Imperfect Information." American Economic Review 71(3):393-410.

Sun, C., and M. Liang. 1982. "Savings in Taiwan, 1953-1980." In Kwoh-Ting $\mathrm{Li}$ and Tzong-Shian Yu, eds., Experiences and Lessons of Economic Development in Taiwan. Taipei: Institure of Economics, Academia Sinica.

Ueda, Kazuo. 1992. Institutional and Regulatory Frameworks for the Main Bank System. Tokyo: University of Tokyo.

Vittas, Dimitri. 1991. "Measuring Commercial Bank Efficiency: Use and Misuse of Bank Operating Ratios." Policy Research Working Paper 806. World Bank, Country Economics Department, Washington, D.C.

World Bank. 1989. World Development Report 1989: Financial Systems and Development. New York: Oxford University Press.

-1993a. The East Asian Miracle: Economic Growth and Public Policy. New York: Oxford University Press.

- 1993b. "Korea Financial Sector Study." East Asia and Pacific Regional Office, Country Department I, Industry and Energy Operations Division, Washington, D.C. Processed.

Yasuda, Ayako. 1992. "The Performance and Roles of Japanese Development Banks." Stanford University, Directed Readings for Professor Joseph E. Stiglitz, Stanford, Calif. Processed.

Yoshino, N. 1992. "History and the Role of Post Office Savings and the Role of Government Financing in Japan." Keio University, Department of Economics, Tokyo. Processed. 
Copyright of World Bank Research Observer is the property of Oxford University Press / USA and its content may not be copied or emailed to multiple sites or posted to a listserv without the copyright holder's express written permission. However, users may print, download, or email articles for individual use. 